\title{
Nilai Sosial Masyarakat Madura dalam Kumpulan Syair Lagu Daerah Madura
}

\author{
Putri Ambarwati, Huriyatul Wardah, dan M. Ovin Sofian \\ Universitas Muhammadiyah Malang \\ putriambarwati.musume@gmail.com \\ hurriyatulwardah17@gmail.com \\ movin.sofian@gmail.com
}

\begin{abstract}
Abstrak
Penelitian ini membahas mengenai nilai sosial masyarakat Madura dalam kumpulan syair lagu daerah Madura. Kajian ini dilakukan dengan tujuan memaparkan tentang nilai-nilai sosial dalam kehidupan masyarakat Madura yang tercermin melalui lagu daerahnya. Dengan adanya penelitian ini diharapkan mampu memberikan manfaat kepada masyarakat agar dapat memaknai lagu daerah tersebut secara mendalam dengan cara mengambil pesan yang disampaikan dalam lagu serta meluruskan streotip orang di luar Madura terhadap masyarakat Madura. Dalam penelitian ini menggunakan pendekatan etika yang sejalan dengan nilai-nilai sosial masyarakat yang dibahas. Teori yang digunakan yaitu teori dari Immanuel Kant dan John Stuart Mill yang membahas mengenai etika sosial. Penelitian ini menggunakan jenis penelitian kualitatif dan sumber data yang digunakan berupa sumber data kontekstual. Pembahasan yang dihasilkan dari penelitian ini yaitu membahas mengenai nilai-nilai sosial yang terdapat dalam beberapa lagu daerah Madura yaitu lagu "Caca aghuna, Re-sere penang, Bhing ana"e, Pajjher Lagghu, dan Tandhu" Majheng. Nilai-nilai yang terefleksikan dalam lagu tersebut yaitu terdiri dari nilai kepedulian dan nilai tanggung jawab.
\end{abstract}

Kata kunci: etika; lagu daerah; madura; nilai sosial

\begin{abstract}
This study explain about social value in a collection of Madura the local song. This study was conducted with the aim of explaining about social values in the life of the Madurese community which is reflected through the local song. So that, this research is expected to provide benefits to the community in order to understanding the value of songs in the area deeply by taking messages delivered in the song and straighten the stereotype of people outside Madura Madurese community. This study used ethical approach which is straight with social values of society discussed. this research uses the theory of Immanuel Kant and John Stuart Mill which discusses social ethics. This research uses qualitative research type. the data source which used in this research is the form of contextual data source. The point to discuss of this research aims to discuss about social values contained in some songs of Madura region such as "Caca aghuna, Re-sere penang, Bhing ana ', Pajjher Lagghu, and Tandhu' Majheng. The values reflected in the song consist of values of caring and value of cooperation.
\end{abstract}


Keywords: ethics; regional song; madura; social value

\section{PENDAHULUAN}

Puisi merupakan salah satu jenis dari karya sastra yang dikenal dari ciri bahasanya yang mengandung makna dan estetika. Hal ini dapat dilihat dari penggunaan bahasa dalam penulisan puisi seperti penggunaan simbol bahasa berupa majas-majas yang terdapat dalam suatu puisi. Bahasa merupakan bahan utama yang berfungsi sebagai ungkapan perasaan, ekspresi dan pikiran pribadi seseorang yang ditulis dalam bentuk balutan kata-kata yang indah (Saini, 1988:3). Dalam pembuatan puisi tidak ada batasan dalam penggunaan bahasa sehingga bahasa dalam puisi bersifat bebas dan tidak terikat. Hal ini memberikan peluang bagi seseorang untuk mengekspresikan pikiran dan perasaannya secara bebas menggunakan bahasa ibu atau bahasa daerahnya.

Keunikan bahasa daerah juga berlaku di daerah Madura. Di setiap daerah antarkabupaten di Madura memiliki ciri khas masing-masing, baik dalam dialek ataupun pemaknaan kata yang menjadi keunikan dalam bahasa tersebut. Bahasa inilah yang menjadi karakteristik dari etnisitas orang Madura sebagai identitas orang Madura saat berada di tempat perantauan, karena kebanyakan tradisi masyarakat Madura pergi merantau ke luar pulau Madura. Menurut Taufiqurrahman (2017:6), Masyarakat Madura itu sendiri juga menyembunyikan penggunaan bahasa antarsesama etnik saat berada di kota perantauan. Hal ini dikarenakan minimnya rasa kebanggaan yang dimiliki oleh masyarakat terhadap bahasanya sendiri yang kebanyakan dari mereka bukan merasa bangga tapi merasa malu saat berkomunikasi menggunakan bahasa ibu di kota perantauan. Perilaku semacam ini tidak hanya berlaku pada bahasa Madura saja tetapi juga pada syair dan lagu-lagu daerah Madura yang saat ini mulai digeser oleh lagu-lagu modern ataupun popular.

Daerah Madura juga kaya akan syair dan lagu-lagu tradisional di daerahnya. Maka dari itu, penyair Madura memanfaatkan bahasanya sendiri dalam pembuatan syair lagu sehingga keunikan dari syair lagu tersebut terletak dalam kekhasan dari bahasa daerahnya. Syairsyair Madura tersebut merupakan hasil dari budaya masyarakat Madura. Kata budaya merupakan kata yang merujuk pada suatu kebiasaan atau adat yang terdapat dalam suatu masyarakat tertentu (Marsuki, 2015:74). Syair lagu khas daerah merupakan cerminan dari kehidupan sosial dan kebudayaan daerah tersebut yang telah ada secara turun temurun sehingga keaslian dari lagu tersebut tetap terjaga dan melekat di dalam kehidupan masyarakat (Sulistyorini \& Andalas, 2017:6; Andalas, 2018:1). Setiap orang memiliki pandangan tersendiri terhadap pemaknaan lagu atau syair daerah tersebut, khususnya dari masyarakat asli daerah Madura.

Syair lagu Madura biasanya sering dinyanyikan oleh anak-anak dan juga orang tua. Pada dasarnya para orang tua dan anakanak menyanyikan lagu-lagu tersebut sebagai hiburan semata, baik orang tua yang ingin menghibur anaknya ataupun anak-anak yang menyanyikan lagu tersebut saat bermain 
dengan teman- temannya. Namun demikian, anak-anak dan orang tua yang menyanyikan lagu-lagu daerah tersebut kurang memahami maksud ataupun makna yang terkandung di dalamnya. Hal ini menyebabkan masyarakat kurang menghargai adanya lagu-lagu daerah yang sudah ada sejak dulu. Padahal, syairsyair daerah, sebagai sebuah sastra lisan, tersebut menjelaskan tentang kehidupan sosial masyarakat Madura yang mencerminkan keadaan masyarakat dan di dalamnya mengandung etika sosial (Andalas, 2015).

Etika sosial membicarakan mengenai kewajiban manusia sebagai anggota masyarakat (Suseno, 1991:7; Sugiarti \& Andalas, 2018: 47-50). Kewajiban tersebut merupakan kewajiban dalam berperilaku baik antarsesama manusia seperti bertindak sopan, menasehati, tolong-menolong dan lain- lain. Di dalam syair tersebut terdapat nilai- nilai etika kehidupan yang dapat dipetik oleh masyarakat seperti syair yang berisi nasihat maupun ajakan dalam hal berbuat kebaikan, dan juga rasa tanggung jawab kepada orang lain sehingga syair-syair tersebut tak hanya berfungsi sebagai hiburan tetapi juga mendidik.

Puisi merupakan salah satu karya sastra yang dapat dikaji dari berbagi macam aspek tertentu (Pradopo, 2012:3). Hal ini juga berlaku pada puisi yang berbentuk sastra lisan. Syair-syair lagu merupakan adaptasi dari sebuah puisi. Syair yang terdapat dalam kumpulan lagu- lagu daerah Madura mengandung makna mendalam yang sangat berpengaruh ataupun memberikan dampak tersendiri terhadap kehidupan sosial masyarakat (Andalas, 2017), seperti syair lagu “Tandhu' Majang” dan “Pajjar Lagghu” yang di dalamnya mengandung makna bahwa masyarakat Madura sebagian besar mata pencahariannya sebagai petani dan nelayan. Namun, hasil yang diperoleh masyarakat mayoritas berasal dari kekayaan laut. Hal ini dikarenakan sebagian besar tanah pulau Madura tidak cocok untuk bercocok tanam.

Masyarakat di luar Madura sering kali memandang orang asli Madura sebelah mata dengan cara mengecap negatif bahwa orang Madura itu identik dengan orang yang keras, garang, dan berperilaku kasar (Rochana, 2012:49). Sebagian besar masyarakat memandang negatif orang Madura dikarenakan istilah Carok yang cukup identik dengan orang Madura. Namun, jika masyarakat luar melihat secara langsung keadaan masyarakat Madura di daerahnya, tidak semua masyarakat daerah tersebut berperilaku seperti yang dipikirkan oleh orang luar. Bahkan etika berperilaku orang-orang Madura yang berbanding terbalik dengan pemikiran masyarakat luar justru banyak tergambar dalam syair-syair lagu orang Madura.

Dari latar belakang yang telah dipaparkan, masalah yang menjadi fokus kajian penelitian ini adalah bagaimana nilainilai sosial masyarakat Madura yang tercermin dalam syair lagu daerah Madura. Penelitian ini dilakukan dengan tujuan untuk memaparkan dan menjelaskan kehidupan sosial masyarakat Madura yang berkaitan dengan etika sosial masyarakat baik dari sikap antarsesama masyarakat dan tanggung jawab terhadap sesama yang tercermin dalam sastra lisan melalui syair lagu daerah Madura tersebut.

Penelitian yang dilakukan terhadap syair lagu Madura ini diharapkan dapat memberikan 
manfaat teoritis dan praktis. Pertama, menambah wawasan dan pengetahuan kepada masyarakat baik masyarakat Madura itu sendiri maupun masyarakat di luar Madura mengenai sastra lisan yang terefleksikan melalui syair lagu daerah Madura dan lagu tersebut memiliki banyak makna dan mencerminkan keadaan masyarakat Madura. Kedua, membantu meningkatkan apresiasi masyarakat maupun mahasiswa terhadap lagu syair-syair daerah dan menerapkan nilai-nilai penting yang tergambar dalam syair lagu tersebut serta memotivasi peneliti lainnya untuk mengkaji secara mendalam lagi mengenai syair-syair lagu yang terdapat di berbagai macam daerah.

Mengenai penelitian syair lagu daerah Madura, sebelumnya juga pernah dilakukan oleh berbagai peneliti lainnya yang pernah dilakukan oleh Moh Fatah Yasin (2017:78) dalam kajian yang berjudul "Ekspresi nilai filosofis Abantal Ombak, Asapo' Angin dalam sastra Madura". Dalam tulisannya Fatah menganalisis beberapa puisi karya Zawawi Imron dengan menggunakan kajian analisis semantik komponential Ruth Kempson. Kajian pada puisi-puisi tersebut dijelaskan secara deskriptif mengenai pemaknaan yang terdapat di dalam puisi. Setelah itu, dikaitkan dengan istilah abantal ombak asapo ${ }^{\text {ee }}$ angin yang terdapat dalam salah satu syair Madura. Dari keseluruhan analisisnya dapat disimpulkan bahwa menurut Fatah masyarakat Madura memiliki pandangan terhadap suatu kehidupan yaitu apabila mereka menginginkan kebahagiaan maka mereka harus merantau dan bekerja keras. Hal ini tergambar dalam ungkapan "abantal ombak asapo "e angin” yang artinya "berbantal ombak dan berselimutkan angin".

Penelitian terdahulu juga pernah dilakukan oleh (Fatmawati, 2017:428), dalam penelitiannya yang berjudul "Cermin Budaya Masyarakat Madura dalam Perspektif Penyair Malang dalam Kumpulan Puisi „Madura: Aku dan Rindu“e Karya Benazir Nafilah”. Di dalam penelitiannya Fatmawati meneliti bait-bait puisi yang mencerminkan tentang budaya masyarakat Madura. Fatmawati juga menjelaskan bahwa terdapat beberapa kebudayaan masyarakat Madura dalam kumpulan puisi yang dianalisis yaitu: budaya melaut, sihr, berladang, penghargaan terhadap orang tua dan pimpinan, celurit, saronen, tongtong, dan lain-lain.

Penelitian lainnya lebih banyak yang memfokuskan pada bahasa pangalem atau pujian yang mengandung berbagai majas. Hal ini pernah dilakukan oleh Rahmat dkk (2013:3) pada penelitiannya yang berjudul Pangalem Bahasa Madura di Bondowoso (Sebuah Kajian Sosiopragmatik). Di dalam penelitiannya Sofyan menganalisis tentang "Bahasa pangalem dalam Bahasa Madura" yang terdiri dari pangalem dengan nama anggota tubuh manusia, pangalem yang berkaitan dengan sifat dan perilaku manusia serta fungsi dan penggunaannya di dalam kehidupan masyarakat. Secara tidak langsung Sofyan memaparkan tentang bagaimana karakter dan perilaku orang-orang Madura.

Selain itu, penelitian yang berkaitan dengan hal-hal berbau majas juga dilakukan oleh Putri (2017:78) pada analisisnya yang berjudul "Metafora Pengungkap Kecantikan dalam Masyarakat Madura", dalam analisisnya Putri memfokuskan metaforanya 
pada objek perempuan Madura. dalam tulisannya Putri memaparkan mengenai kecantikan perempuan Madura yang tercermin dalam majas-majas metafora dalam Bahasa Madura. Penelitian ini mirip dengan penelitian yang dilakukan oleh Sofyan dkk, hanya saja penelitian Putri lebih fokus pada pujian yang menggambarkan perempuan Madura.

Pada penelitian-penelitian terdahulu lebih banyak terfokus pada pengkajian puisi-puisi Madura, majas- majas Madura serta bahasa pangalem (pujian) yang terbentuk dalam bahasa kiasan Madura. Penelitian tersebut dilakukan untuk memberikan gambaran umum masyarakat Madura terutama pada kepribadiannya. Namun penelitian ini berbeda dengan penelitian sebelumnya, dikarenakan peneliti akan mengkaji secara komprehensif mengenai kehidupan masyarakat Madura yang mengandung nilainilai sosial dan memiliki dampak positif dalam kehidupan masyarakat.

Maka dari itu, penelitian ini merupakan tindak lanjut dari peneliti sebelumnya yang akan mengupas secara lebih dalam mengenai masyarakat Madura. Pentingnya penelitian ini yaitu untuk mengetahui kehidupan dan nilainilai sosial masyarakat Madura yang tercermin dalam syair lagu Madura. Dengan mengetahui nilai nilai tersebut, banyak hal yang bisa dipetik dan diaplikasikan dalam keseharian masyarakat yang terkandung dalam syair-syair nasihat Madura. Selain itu, melalui penelitian ini akan memberikan penjelasan yang lebih komprehensif mengenai kehidupan masyarakat Madura yang tercermin dalam syair lagunya untuk memperbaiki pandangan atau pemikiran negatif masyarakat di luar Madura yang selalu memandang masyarakat
Madura itu orang yang keras, garang, dan berperilaku kasar.

Berdasarkan pemaparan tersebut, peneliti memilih objek kajian Syair lagu "Resere Penang", "Caca Aghuna", "Bing Ana'”, "Tandhu' Majheng”, dan "Pajjhar Lagghu”, untuk diteliti lebih lanjut dalam kajian ini karena di dalam lagu-lagu tersebut berisi tentang nasehat agar masyarakat berperilaku baik dan berbicara sopan santun terhadap sesama serta juga mengandung tentang kehidupan kerja sama antarmasyarakat. Namun, peneliti hanya memfokuskan pada satu aspek yaitu nilai sosial di dalam kehidupan masyarakat yang terefleksikan dalam syair lagu Madura. Maka dari itu penulis akan menggunakan pendekatan Etika yang tidak berlandaskan pada teori akan tetapi menggunakan konsep-konsep setika sosial yang berkaitan dengan nilai sosial masyarakat. Peneliti menggunakan konsep tersebut yang berkaitan dengan syair-syair lagu Madura yang mencerminkan perilaku yang mengandung nilai sosial dalam kehidupan masyarakat Madura dan diciptakan oleh penyair sebagai alat yang bertujuan untuk menyejahterakan masyarakat melalui nilai nilai sosial di dalamnya. Peneliti akan menjelaskan keadaan sosial masyarakat yang digambarkan dalam syair lagu, peneliti juga akan membandingkannya dengan keadaan nilai sosial masyarakat di Madura.

\section{METODE}

Penelitian ini merupakan penelitian kualitatif yang diungkapkan melalui data- data kualitatif. Data kualitatif tersebut disampaikan dalam bentuk kata-kata berupa kalimat, uraian serta cerita pendek (Andalas, 2017:187). Maka 
dari itu, data kualitatif diperoleh melalui pembacaan Syair lagu daerah Madura dan kemudian diproses kembali menggunakan metode deskriptif analitik yang tidak hanya menguraikan akan tetapi juga menjelaskan atau memberikan pemahaman mengenai faktafakta yang terdapat di dalam syair lagu dan dianalisis berdasarkan teori.

Pendekatan yang digunakan dalam penelitian ini adalah pendekatan etika yang berfokus pada nilai-nilai kehidupan sosial masyarakat yang terefleksikan dalam syair lagu Madura. Sumber data yang digunakan adalah sumber data primer yaitu berupa syair lagu Madura yang terdiri dari beberapa judul, yaitu "Re-sere Penang", "Caca Aghuna", "Bing Ana'”, "Tandhu' Majheng”, "Pajjhar Lagghu", dan "Kerapan Sapi", sedangkan data yang digunakan berupa lirik-lirik lagu yang terdapat dalam syair lagu tersebut.

Teknik pengumpulan data pada penelitian ini menggunakan teknik wawancara yang tidak terstruktur. Wawancara ini merupakan wawancara yang bebas sehingga peneliti tidak terpaku pada penggunaan pedoman wawancara yang disusun secara sistematis dan dipersiapkan terlebih dahulu untuk mendukung pengumpulan datanya (Sugiyono, 2017:140). Dalam penelitian ini, peneliti menggunakan wawancara untuk mengumpulkan informasi dengan mewawancarai salah satu masyarakat Madura untuk menggali informasi lebih rinci mengenai lagu daerah Madura tersebut. Masyarakat madura yang diwawancarai oleh peneliti yaitu Ibu Hj. Siti Mahmudah berusia 60 tahun yang berasal dari Desa Tlontoraja, Pasean, Pamekasan, Madura untuk memberikan informasi mengenai lirik lagu dan Mega
Rukmana berusia 20 tahun yang berasal dari Desa Tanjung, Pademawu, Pamekasan, Madura untuk memberikan informasi mengenai nada lagu. Setelah mendapatkan data dari wawancara yang dilakukan, maka peneliti masih melakukan beberapa tahapan untuk mengumpulkan data yang lebih akurat. Pertama, peneliti membaca dan memahami maksud dari lirik syair tersebut agar peneliti mampu menangkap informasi yang terkandung dalam syair tersebut. Kedua, peneliti mengidentifikasi nilai-nilai sosial yang tergambar di dalam syair tersebut. Selanjutnya, peneliti mengumpulkan data dengan mencari lirik syair yang berkaitan dan menggambarkan etika sosial masyarakat yang mengandung nilai-nilai sosial.

Dalam menganalisis data, peneliti menggunakan teknik analisis isi yaitu teknik yang dilakukan dengan menginterpretasi data menggunakan daya nalar atau berpikir kritis dan tidak hanya menjelaskan data. Jadi, di dalam teknik analisis isi data ini, peneliti tidak hanya menjelaskan secara deskriptif akan tetapi menjelaskan secara kritis mengenai makna yang tersirat di dalam data. Peneliti mengkaji dan mendeskripsikan nilai sosial yang tergambar dalam syair lagu Madura tersebut.

Pengecekan keabsahan terhadap kajian ini menggunakan validitas diskusi sejawat dan ahli. Menurut Moleong (dalam Bungin, 2010:258) diskusi tersebut dilakukan dengan menghasilkan pandangan kritis pada hasil penelitian, temuan teori yang substantif, membantu pengembangan ke langkah selanjutnya, dan menilai pandangan lain sebagai pembanding. Dengan menggunakan kevaliditasan tersebut peneliti akan mampu 
mengklarifikasi kesalahan atau kekurangan dari penafsiran pihak lain sehingga peneliti mampu mengungkapkan kebenaran dari hasil akhir penelitian.

\section{HASIL DAN PEMBAHASAN}

Menurut Lillie (dalam Zubair, 1990:16) etika merupakan ilmu pengetahuan yang bersifat normatif dan bertugas memberikan pertimbangan terhadap baik atau buruknya perilaku manusia dalam masyarakat. Etika sangat berhubungan dengan kehidupan sosial masyarakat yang berisi nilai-nilai dan tata cara hidup yang baik. Tata cara dan aturan hidup tersebut merupakan suatu perilaku yang sudah menjadi kebiasaan di dalam kehidupan bermasyarakat. Hal ini sangat berkaitan dengan etika sosial dalam masyarakat.

Etika sosial adalah cabang etika yang merupakan filsafat dari moralitas. Etika sosial berkaitan dengan hubungan atau interaksi dalam berperilaku antarindividu di dalam kehidupan masyarakat yang telah menjadi suatu kebiasan. Etika sosial membahas mengenai pemikiran kritis tentang kewajiban dan tanggung jawab manusia sebagai bagian dari anggota masyarakat (Suseno, 1991:9). Sebagaimana hal tersebut, etika berperan dalam membantu masyarakat untuk dapat bertindak secara bebas dalam melaksanakan segala hal namun harus berdasarkan aturan dalam kehidupan masyarakat yang merupakan kewajibannya untuk mematuhi dan melaksanakannya serta dari tindakan tersebut pada nantinya dapat dipertanggungjawabkan. Etika sosial berkaitan dengan hubungan atau interaksi dalam berperilaku antarindividu di dalam kehidupan masyarakat yang mengatur bagaimana cara masyarakat berperilaku satu sama lain.

Etika sosial berhubungan erat dengan nilai-nilai sosial dalam kehidupan masyarakat. Dari adanya etika sosial terbentuklah suatu nilai-nilai sosial yang terdapat di lingkungan sekitar masyarakat. Salah satu adanya etika sosial dari masyarakat Madura adalah adanya suatu lagu daerah yang selalu dinyanyikan oleh para anak-anak saat bermain dan oleh orang tua yang menyanyikan lagu untuk anaknya. Lagu tersebut merupakan warisan atau hal yang telah turun temurun dari satu generasi ke generasi yang lainnya.

Di dalam lagu syair daerah tersebut terdapat nilai-nilai sosial yang direfleksikan melalui lirik lagu. Lagu tersebut memaparkan keadaan suatu masyarakat. Salah satunya yaitu lagu asal daerah Madura, di dalamnya menggambarkan sikap ataupun perilaku antarmasyarakatnya. Hal tersebut dapat dilihat dari nilai-nilai yang terkandung di dalamnya yang terdiri dari, 1) nilai kepedulian, yaitu nilai saling menasehati dalam hal kebaikan, 2) nilai tanggung jawab, yang tegambar pada perilaku masyarakat saat melakukan pekerjaan yang dideskripsikan melalui mata pencaharian masyarakat Madura. Nilai-nilai tersebut akan dikupas dan dipaparkan lebih lanjut dengan penjelasan sebagai berikut:

\section{Nilai Kepedulian}

\section{Saling Menasehati}

\begin{tabular}{|l|l|}
\hline \multicolumn{2}{|c|}{ Lagu “Caca Aghuna” (Kata yang bermanfaat) } \\
\hline Bahasa Madura & \multicolumn{1}{|c|}{ Bahasa Indonesia } \\
\hline “Ya' tampar ya' & Ini tali, ini tali, \\
tampar, Mulet & Melingkar masuk ke \\
nyono' ka cengkol, & siku, \\
Mon lapar yu' & Kalau lapar ayo \\
nono tela sapekol, & bakar tela sepikul, \\
\hline
\end{tabular}




\begin{tabular}{|l|l|}
\hline Ka'korang, ka' & Kak kurang, kak \\
korang, ka' korang, & kurang, kak kurang, \\
Mon coma neng & Kalau hanya tela \\
sapekol, Arapa ma' & sepikul. Kenapa harus \\
pada & pada sombong \\
bongsombongan, & sombongan, \\
Acaca ta' mambhu & Berbicara tak \\
ongnaongan, & usah............ \\
Lebbi becce'caca & $\ldots \ldots$, \\
seaghuna, & Lebih baik berbicara \\
& yang berguna, \\
Nyauwaghi ka & Menjauhkan kejelekan \\
jhuba'panyana, & ...., \\
Arapa arapa, & \\
bhujung bada & Kenapa, kenapa, \\
eroma, & bhujung ada di rumah, \\
Acaca, acaca & Berbicara, \\
ngangghuya & berbicara \\
tatakrama, & menggunakan \\
Yu' kanca & tatakrama, Ayo \\
kakabbhi, & berteman semua, \\
Yu' kanca pada a & Ayo berteman \\
alako se aghuna. & kegiatan yang berguna. \\
(Azhar, 2009:5) & \\
\hline
\end{tabular}

Lagu tersebut yaitu berisi tentang nasihat bahwa kita tidak boleh berperilaku sombong kepada sesama, karena sombong itu sikap membanggakan diri sendiri yang tidak ada manfaatnya. Lebih baik berbicara dan berperilaku yang berguna dan memberikan manfaat kepada semua orang, baik dari si pembicara maupun pendengarnya. Selain memberikan manfaat kepada semua orang, menjauhkan kita dari kejelekan. Berbicara tidak asal berbicara ataupun asal bunyi saja, berperilaku pun tidak boleh semena-mena. Berbicara dan berperilaku terhadap orang lain itu harus memperhatikan atau menggunakan tatakrama yang baik dalam berbicara terutama saat berbicara dengan orang yang lebih tua.

Etiket dalam berbicara dengan orang tua dituntut agar berbicara dan bersikap sopan (Salam, 1997:62). Di dalam masyarakat Madura sendiri memiliki aturan dan tatakrama berbahasa saat berkomunikasi maupun berbicara dengan oran lain. Hal tersebut dipaparkan melalui tingkatan berbahasa dalam bahasa Madura. Masyarakat Madura memiliki tiga macam tingkatan berbahasa yaitu bahasa

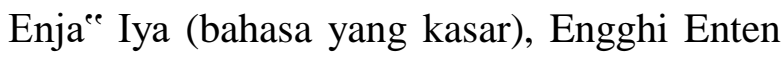
(bahasa yang sedang/tidak kasar dan tidak halus), dan Engghi Bunten (bahasa halus). Ketiga tingkatan bahasa tersebut digunakan orang Madura dengan melihat dengan siapa dulu mereka berbicara.

Masyarakat madura sangat kental dengan tatakrama berbicara dengan orang lain terutama saat berbicara dengan orang tua. Anak-anak sangat ditekankan untuk berbicara sesopan mungkin saat berkomunikasi dengan orang tua ataupun orang yang lebih tua darinya. Hal ini dilakukan agar anak-anak pada nantinya terbiasa dengan ajaran-ajaran tersebut dan menjadi kebiasaan dalam kehidupan sehari-hari.

Dengan adanya nilai kepedulian dengan sikap saling menasehati yang terefleksikan di dalam lirik lagu daerah Madura memberikan gambaran bahwa nilai sosial masyarakat Madura yaitu terletak pada nasehat atau mengingatkan satu sama lain agar memiliki tatakrama dalam berbicara, yang lebih menekankan agar masyarakat dapat berbicara secara sopan dan santun serta membicarakan mengenai hal-hal yang bermanfaat antarsesama masyarakat lainnya.

Dengan adanya kepedulian masyarakat tentang tatakrama dalam berbicara akan memberikan manfaat bagi masyarakat itu sendiri, misalnya pada anak-anak yang sejak kecil diajari tatakrama dalam berbicara maka nantinya pada saat mereka dewasa, mereka akan memiliki banyak teman dan akan lebih dihargai oleh orang lain. 


\begin{tabular}{|l|l|}
\hline \multicolumn{2}{|c|}{ Lagu Re-Sere Penang } \\
\hline Bahasa Madura & Bahasa Indonesia \\
\hline Re-sere penang, & Re-sere pinang, \\
Penangnga penang & Pinangnya pinang \\
jambe, Maju kaka', & jambe, Ayo kakak, ayo \\
maju ale', Pabaghus & adik, Perbaiki tingkah \\
tengkana, lako & laku, lakukan hal yang \\
becce', & baik, \\
Kalellan e ka'dhinto. & Kalellan ka'dhinto. \\
\hline
\end{tabular}

Maksud dari lagu tersebut memiliki makna yang sama seperti lagu sebelumnya yaitu "caca aghuna" yaitu mengajak kita untuk memperbaiki tingkah laku, baik anak-anak, remaja, maupun orang tua. Hal ini dikarenakan semakin modernnya jaman saat ini menyebabkan semakin banyak anak-anak, remaja dan orang tua yang kurang memperhatikan tingkah laku mereka. Tak sedikit dari mereka yang berperilaku seenaknya tanpa memperhatikan tingkah laku yang baik maupun buruk serta bersikap acuh tak acuh satu sama lain. Selain mengajak kita untuk memperbaiki tingkah laku, syair lagu tersebut mengajak kita untuk melakukan hal yang baik sehingga bisa memberikan banyak manfaat kepada diri sendiri dan juga orang lain.

Etika normatif merupakan norma- norma yang mengatur tingkah laku atau cara berperilaku pada manusia dalam bertindak. Salah satunya yaitu norma sopan santun yang di dalamnya mengatur pola peilaku dan sikap seseorang (Salam, 1997:4). Sebagaimana pesan yang disampaikan melalui lirik lagu madura tersebut, di dalamnya memaparkan mengenai sikap maupun perilaku masyarakat Madura. Hal tersebut menunjukkan bahwa kehidupan masyarakat Madura cenderung atau lebih menjujung tatakrama terutama dalam berbicara dengan orang lain. Hal itu dapat dilihat dari adanya aturan berbahasa yang telah diatur dalam beberapa tingkatan berbahasa.
Dengan adanya tingkatan berbahasa dalam berbicara tersebut akan membuat masyarakat berhati-hati saat berbicara dan lebih memperhatikan manfaat dari pesan yang disampaikan sehingga hal tersebut dapat memberikan dampak positif di lingkungan masyarakat.

\section{Saling Menasehati Melalui Sindiran}

\begin{tabular}{|c|c|}
\hline \multicolumn{2}{|c|}{ Lagu Bing Ana (Anak Gadis) } \\
\hline Bahasa Madura & Bahasa Indonesia \\
\hline $\begin{array}{l}\text { Bing ana', } \\
\text { Ta'endha' nyempang } \\
\text { lorongnga, } \\
\text { Bing ana', } \\
\text { Mon Lorong tombuwi } \\
\text { kolat. }\end{array}$ & $\begin{array}{l}\text { Anak Gadis, } \\
\text { Tidak mau melewati } \\
\text { jalannya, } \\
\text { Anak gadis, } \\
\text { Kalau jalannya } \\
\text { ditumbuhi tanaman. }\end{array}$ \\
\hline $\begin{array}{l}\text { Bing ana', } \\
\text { Ta'endha' ngala' } \\
\text { toronna, } \\
\text { Bing ana', } \\
\text { Mon toronna reng ta', } \\
\text { pelak. }\end{array}$ & $\begin{array}{l}\text { Anak gadis, } \\
\text { Tidak mau mengambil } \\
\text { keturunannya. } \\
\text { Anak gadis, } \\
\text { Kalau dari keturunan } \\
\text { tidak baik. }\end{array}$ \\
\hline $\begin{array}{l}\text { Bing ana', } \\
\text { Sapa rowa andhi', } \\
\text { tarnya', } \\
\text { Bing ana', } \\
\text { Mano' poter le' le' } \\
\text { pote. }\end{array}$ & $\begin{array}{l}\text { Anak gadis, } \\
\text { Siapa itu yang punya } \\
\text { bayam, } \\
\text { Anak gadis, } \\
\text { Burung perkutut } \\
\text { berwarna putih. }\end{array}$ \\
\hline $\begin{array}{l}\text { Bing ana', } \\
\text { Sapa rowa andhi' } \\
\text { ana', } \\
\text { Bing ana', } \\
\text { Sela penter becce' ate, }\end{array}$ & $\begin{array}{l}\text { Anak gadis, } \\
\text { Siapa itu yang punya } \\
\text { anak, } \\
\text { Anak gadis, } \\
\text { Sudah pintar, baik } \\
\text { hati pula }\end{array}$ \\
\hline $\begin{array}{l}\text { Bing ana', } \\
\text { Sapa rowa andhi' } \\
\text { tarnya', } \\
\text { Bing ana', } \\
\text { Plappa kencorla- } \\
\text { kellana. }\end{array}$ & $\begin{array}{l}\text { Anak gadis, } \\
\text { Siapa itu punya bayam, } \\
\text { Anak gadis, } \\
\text { Bumbu kencurnya } \\
\text { kellana. }\end{array}$ \\
\hline $\begin{array}{l}\text { Bing ana', } \\
\text { Sapa rowa andhi' } \\
\text { ana', } \\
\text { Bing ana', } \\
\text { Andhap asor pon } \\
\text { cacana. }\end{array}$ & $\begin{array}{l}\text { Anak gadis, } \\
\text { Siapa itu punya anak, } \\
\text { Anak gadis, } \\
\text { Sopan santun cara } \\
\text { bicaranya. }\end{array}$ \\
\hline $\begin{array}{l}\text { Bing ana', } \\
\text { Rampa' naong }\end{array}$ & $\begin{array}{l}\text { Anak gadis, } \\
\text { Bersama teduhnya }\end{array}$ \\
\hline
\end{tabular}




\begin{tabular}{|l|l|}
\hline bringen korong, & $\begin{array}{l}\text { beringin mengurung, } \\
\text { Bing ana', } \\
\text { Bantal lama'ka } \\
\text { poncana. }\end{array}$ \\
& $\begin{array}{l}\text { Anak gadis, } \\
\text { Bantal alas ke } \\
\text { puncaknya. }\end{array}$ \\
Bing ana', & Anak gadis, \\
Soka' along saleng & Suka saling tolong \\
tolong & menolong, \\
Bing ana', & Anak gadis, \\
Bakal bannya' & Akan banyak teman- \\
cakancana & temannya \\
\hline
\end{tabular}

Lagu yang berjudul bing ana ${ }^{e e}$ tersebut merupakan salah satu jenis lagu yang digambarkan mirip seperti pantun, hanya saja bentuk akhiran sajaknya yang berbeda-beda dan juga sampiran serta isinya terletak dalam perbait yaitu satu bait merupakan sampiran, satu bait selanjutnya merupakan isi atau pesan dan begitu seterusnya. Di dalam lagu tersebut berfokus pada nasehat untuk seorang anak perempuan yang terdiri dari 4 pesan atau nasehat.

Pesan pertama yaitu terletak pada bait kedua yang memaparkan tentang sindiran kepada anak perempuan yang tidak baik terhadap antarsesama, tidak akan ada yang ingin menjadikannya menantu. Hal itu digambarkan pada kata " $T a$ ' endha' ngala' toronna, Mon toronna reng ta' pelak" di dalam kutipan lirik lagu tersebut memiliki makna yaitu "Tidak mau mengambil keturunan, Kalau dari keturunan yang tidak baik". Melalui kutipan tersebut seorang penyair menyindir anak perempuan yang tidak memiliki karakter atau sifat yang baik dan secara tidak langsung lagu tersebut memiliki pesan agar anak perempuan sebaiknya memiliki sifat yang baik, luar dan dalam. Masyarakat Madura akan mendidik anak-anak gadisnya untuk berperilaku baik dan sopan sejak dini, melalui lirik lagu ini akan membantu mengingatkan masyarakat Madura terutama anak perempuan untuk memiliki tatakrama berperilaku yang baik.

Pesan kedua dijelaskan dalam bait keempat yang terdapat dalam kutipan lirik "Sapa rowa andhi' ana', Sela penter becce' ate" yang artinya adalah "Siapa itu yang punya anak, Sudah pintar, baik hati pula. Melalui lirik lagu tersebut penyair menyampaikan pesan agar seorang anak perempuan tidak hanya pintar dan memiliki kecerdasan secara intelektual namun juga harus memiliki kepribadian dan karakter yang baik, baik karakter yang terlihat dari luar maupun karakter yang ada di dalam hatinya. Di dalam lagu tersebut secara tidak langsung penyair menyindir bahwa seorang anak perempuan harus pintar dan cerdas serta juga memiliki kepribadian yang baik. Di dalam kehidupan masyarakat Madura walaupum ada anak yang pintar dan cerdas akan dikucilkan nantinya serta tidak terlalu diperhatikan. Hal ini karena pertama kali yang dilihat oleh orang Madura adalah perilakunya baik dari tingkah laku baik dari seseorang maupun dari tingkah laku terhadap sesama dan orang-orang yang disekitarnya.

Pesan selanjutnya disampaikan penyair melalui bait keenam, yang terdapat pada lirik 'Sapa rowa andhi' ana', Andhap asor pon cacana" yang memiliki arti Siapa itu punya anak, Sopan santun cara bicaranya. Di dalam lirik tersebut menjelaskan bahwa anak perempuan harus memilik sikap sopan santun dalam berbicara, Dalam kehidupan orang Madura masyarakat memiliki aturan tata cara berbicara dengan orang lain, baik berbicara dengan orang yang lebih muda, dengan teman sebaya, dan terhadap orang yang lebih tua. 
Pesan yang terakhir digambarkan pengarang pada bait terakhir yaitu pada bait kedelapan yang terdapat pada lirik "Soka' along saleng tolong, Bakal bannya' cakancana." Lirik tersebut memiliki makna "Suka saling tolong menolong, Akan banyak teman-temannya", maksud dari lirik tersebut yaitu, bahwa orang yang suka saling tolong menolong dan membantu antarsesama akan memiliki banyak teman di sekelilingnya. Di dalam keseharian masyarakat Madura tidak bisa terlepas dari kehidupan yang saling membantu antarsesama terutama dengan tetangga, orang yang belum dikenal, dan orang sudah lama dikenalnya. Hal ini dikarenakan masyarakat Madura sudah memiliki kebiasaan yang kental dan sudah mandarah daging dalam kehidupannya, seperti membagi makanan kepada tetangga dan orang lain, membantu tetangga apabila sedang ada perayaan tahlilan ataupun pernikahan tanpa mengaharapkan pamrih, membantu orang lain yang mengalami kesulitan, dan masih banyak lagi yang lainnya. Hal-hal tersebut tidak bisa terlepas begitu saja dan hilang di dalam kehidupan masyarakat Madura karena hal tersebut merupakan suatu identitas dan nilai etika yang terdapat dalam kehidupan masyarakat Madura.

Deskripsi dari lagu tersebut-tersebut sejalan norma moral yang membahas mengenai aturan dalam bersikap dan berperilaku yang mengacu pada baik buruknya manusia sebagai manusia (Salam, 1997:5). Sebagaimana yang tergambar dalam lagu bing ana $^{\text {ee }}$ yang memaparkan mengenai cara bersikap bagi seorang perempuan. Masyarakat madura memiliki streotip bahwa perempuan yang tidak baik tingkah laku, cara bicara, dan hatinya, tidak akan dijadikan seorang menantu karena para Ibu di lingkungan masyarakat madura sangat memperhatikan hal-hal tersebut dalam menentukan pasangan untuk anakanaknya. Hal tersebut dilakuakan dengan tujuan agar masyarakat Madura terutama seorang perempuan memiliki perilaku dan cara bicara yang sopan santun. Selain itu dalam lagu tersebut memaparkan agar masyarakat melatih anaknya sejak dini untuk senantiasa saling tolong menolong satu sama lain.

\section{Nilai Tanggung Jawab}

\section{Sebagai Nelayan}

\begin{tabular}{|c|c|}
\hline \multicolumn{2}{|c|}{ Lagu Tandhu' Majheng } \\
\hline Bahasa Madura & Bahasa Indonesia \\
\hline $\begin{array}{l}\text { Ngapote wa' lajarra e } \\
\text { tangale } \\
\text { Reng majheng tantona } \\
\text { la padha mole }\end{array}$ & $\begin{array}{l}\text { Memutih, layarnya } \\
\text { sudah terlihat } \\
\text { Orang nelayan pastinya } \\
\text { sudah pada pulang }\end{array}$ \\
\hline $\begin{array}{l}\text { Mon tangghu dari ambet } \\
\text { pajalanna } \\
\text { Mase bannya'a onggu } \\
\text { le- ollena }\end{array}$ & $\begin{array}{l}\text { Kalau dilihat dari } \\
\text { lambat jalan perahunya } \\
\text { Sepertinya banyak } \\
\text { Benar yang } \\
\text { diperolehnya }\end{array}$ \\
\hline $\begin{array}{l}\text { O... mon ajelling } \\
\text { odhi'na oreng } \\
\text { majhengan }\end{array}$ & $\begin{array}{lr}\text { O... kalau dilihat } \\
\text { hidupnya } \\
\text { nelayan }\end{array}$ \\
\hline $\begin{array}{l}\text { Abantal ombha' sapo' } \\
\text { angen salanjhangnga }\end{array}$ & $\begin{array}{l}\text { Berbantal ombak } \\
\text { Berselimut angin, } \\
\text { sepanjang hidupnya }\end{array}$ \\
\hline $\begin{array}{l}\text { Olle ollang paraona } \\
\text { allajare } \\
\text { Olle ollang allajare ka } \\
\text { Madhura }\end{array}$ & $\begin{array}{l}\text { Olle ollang perahunya } \\
\text { mau berlayar } \\
\text { Olle ollang mau } \\
\text { berlayar ke Madhura }\end{array}$ \\
\hline $\begin{array}{l}\text { Olle ollang paraona } \\
\text { allajare }\end{array}$ & $\begin{array}{l}\text { Olle ollang } \\
\text { perahunya mau } \\
\text { berlayar }\end{array}$ \\
\hline $\begin{array}{l}\text { Olle ollang paraona } \\
\text { allajare }\end{array}$ & $\begin{array}{l}\text { Olle ollang } \\
\text { perahunya mau } \\
\text { berlayar }\end{array}$ \\
\hline $\begin{array}{l}\text { Reng majang raja } \\
\text { ongghu babajana }\end{array}$ & $\begin{array}{l}\text { Orang nelayan } \\
\text { Sungguh besar } \\
\text { bahayanya }\end{array}$ \\
\hline
\end{tabular}




\begin{tabular}{|l|l|}
\hline $\begin{array}{l}\text { Kabilang alako bandha } \\
\text { nyabana }\end{array}$ & $\begin{array}{l}\text { Bisa dibilang bekerja } \\
\text { dengan bertaruh } \\
\text { (Azhar, 2009:7) }\end{array}$ \\
\hline
\end{tabular}

Maksud dari lagu tersebut adalah mengisahkan kehidupan nelayan dalam mengarungi lautan luas, dan dikisahkan juga bahwa pekerjaan sebagai nelayan itu bukanlah pekerjaan yang mudah, tetapi disana para nelayan bertaruh nyawa demi menafkahi keluarganya.

Dapat kita cermati pada bait pertama dimana lagu tersebut bercerita tentang para nelayan yang kembali dari lautan mengadu nasib di lautan luas. Berbeda dengan bait terakhir, bait terakhir lebih menekankan pada resiko yang ditanggung oleh para nelayan dalam bekerja mengarungi lautan ganas, seperti yang dipaparkan dalam lagunya bahwa pekerjaan ini merupakan pekerajan yang mempertaruhkan nyawa.

Suatu tanggung jawab memiliki tiga unsur yaitu kesadaran, kecintaan, dan keberanian (Salam, 1997:33). Kesadaran bermakna bahwa seseorang yang melakukan hal tersebut menyadari akibat ataupun resiko yang ditanggung dan dipikulnya dan mempertanggungjawabkan apa yang telah dilakukannya. Kecintaan memiliki makna bahwa yang dilakukan oleh seseorang adalah kesediaan dirinya untuk rela berkorban demi apa yang telah ditanggungjawabkannya. Sementara keberanian, merupakan sikap berani dan ikhlas melakukan hal yang dipikulnya.

Sebagaimna prajurit Indonesia yang sadar akan tanggung jawabnya untuk membela tanah airnya yang dicintainya dengan memberanikan diri berperang demi memenuhi tanggungjawab terhadap negaranya. Hal ini sejalan dengan tanggungjawab yang telah dipikul oleh masyarakat Madura, yang mengorbankan hidupnya dengan berlayar di tengal Samudra demi menghidupi keluarganya dan memenuhi tanggungjawabnya sebagai kepala keluarga.

Masyarakat Madura sendiri dalam bekerja sebagai nelayan tidak melakukannya secara individu akan tetapi secara berkelompok dan gotong royong sehingga dalam dunia pekerjaan untuk memenuhi tanggungjawabnya sebagai nelayan, mereka memprioritaskan kerja sama dan saling membantu satu sama lain baik antarindividu ataupun kelompok. Hal tersebut selalu dilakukan oleh masyarakat Madura karena telah menjadi suatu etika sosial di dalam kehidupan masyarakat.

\section{Sebagai Petani}

\begin{tabular}{|l|l|}
\hline \multicolumn{2}{|c|}{ Lagu 'Pajjhar Lagghu" } \\
\hline \multicolumn{1}{|c|}{ Bahasa Madura } & \multicolumn{1}{c|}{ Bahasa Indonesia } \\
\hline $\begin{array}{l}\text { Pajjhar lagghu arena } \\
\text { pon nyonara. }\end{array}$ & $\begin{array}{l}\text { Fajar dipagi hari sudah } \\
\text { bersinar. }\end{array}$ \\
$\begin{array}{l}\text { Bapa' tane se tedung } \\
\text { pon jhagha'a. }\end{array}$ & $\begin{array}{l}\text { Bapak petani yang } \\
\text { tidur sudah mulai } \\
\text { terbangun. }\end{array}$ \\
$\begin{array}{l}\text { Ngala' are' ben } \\
\text { landhu' tor capengnga. }\end{array}$ & $\begin{array}{l}\text { Mengambil sabit dan } \\
\text { cangkul serta topinya. }\end{array}$ \\
$\begin{array}{l}\text { A jhalanannaghi } \\
\text { sarat kawajibhan. }\end{array}$ & $\begin{array}{l}\text { Menjalankan } \\
\text { kewajibannya. }\end{array}$ \\
$\begin{array}{l}\text { Atatamen } \\
\text { mabannya' hasel } \\
\text { bhumena. }\end{array}$ & $\begin{array}{l}\text { Menanam untuk } \\
\text { memperbanyak hasil } \\
\text { buminya }\end{array}$ \\
$\begin{array}{l}\text { Mama'mor nagharana } \\
\text { tor bangsana. } \\
\text { (Azhar, 2009:7) }\end{array}$ & $\begin{array}{l}\text { Memakmurkan negara } \\
\text { dan juga bangsanya. }\end{array}$ \\
\hline
\end{tabular}

Maksud dari lagu ini yaitu mengisahkan tentang kehidupan petani dan bercocok tanam, pada bait pertama mengisahkan bahwa para petani sejak pagi buta sudah bangun dan mulai beraktifitas di ladang untuk bercocok tanam. 
Pada bait ke lima memaparkan tentang seorang petani yang berjuang untuk menambah penghasilan hidupnya sebagai petani yang selalu hidup dengan panas dan gersangnya persawahan. Sedangkan pada bait terakhir digambarkan bahwa apa yang dilakukan petani sangat bermanfaat bagi negara dan bangsanya, karena dengan jerih payah petanilah negara tidak kekurangan pasokan pangan. Masyarakat Madura yng bercocok tanam dan bertani, melakukan hak tersebut untuk memenuhi kebutuhan keluarganya.

Dalam lagu "Pajjher Lagghu” juga menyampaikan bahwa semangat masyarakat Madura dimulai sejak terbitnya matahari. Hal itu menandakan bahwa masyarakat merupakan orang-orang yang pekerja keras bukan orang yang bermalas-malasan serta juga orang yang bersemangat dan berlomba dengan fajar. Dengan demikian pengarang ingin menyampaiakan pada khalayak umum betapa kerasnya kehidupan petani dalam melalukan suatu pekerjaan yang dilakukan secara bersama-sama.

Pekerja sosial memiliki tanggung jawab dalam berupaya meningkatkan dan mengembangkan kesejahteraan masyarakat antara yang satu dengan yang lainnya (Salam, 1997:158). Dalam kehidupan masyarakat Madura bercocok tanam merupakan tanggungjawab dalam menafkahi keluarganya. Selain itu, di masyarakat Madura saat bertani mereka melakukannya hal tersebut dengan bergotong-royong. Hal tersebut sudah menjadi kebiasaan kehidupan sosial masyarakat Madura itu sendiri untuk tetap saling bekerja sama dalam suatu pekerjaan satu sama lain. Bekerja sama, gotong royong, dan saling membantu satu sama lain adalah suatu kewajiban sebagai masyarakat.

Tidak hanya dalam hal mata pencahariannya saja, tetapi lewat syair Madura yang dijelaskan sebelumnya berisi tentang hal mengenai saling mengingatkan atau menasehati antara satu dengan yang lain seperti dalam syair lagu "Re-Sere Penang" yang memiliki makna berupa nasehat untuk saling berperilaku baik terhadap sesama. Hal tersebut menunjukkan bahwa masyarakat Madura tidak hanya memiliki perilaku yang baik akan tetapi juga memiliki karakter pekerja keras dan bertanggung jawab, tidak seperti perspektif masyarakat di luar Madura yang menganggap orang Madura itu kasar dan jahat.

\section{KESIMPULAN}

Berdasarkan dari penelitian yang telah dilakukan mengenai nilai sosial yang terdapat dalam lagu daerah Madura. Maka dapat disimpulkan bahwa terdapat dua nilai sosial. Pertama yaitu nilai kepedulian, yang terdiri dari kepedulian dengan saling menasehati secara langsung dan menasehati secara tidak langsung atau melalui sindiran. Nilai kepedulian mengenai saling menasehati secara langsung dipaparkan melalui lirik lagu daerah madura, pada lagu yang berjudul Caca Aghuna dan Re-sere Penang. Sementara itu, nilai kepedulian yang mencerminkan mengenai saling menasehati secara tidak langsung atau melalui sindiran dapat dilihat dalam lirik lagu daerah yang berjudul Bing Anae

Dari keseluruhan lagu tersebut intinya memiliki makna dan pesan yang sama yaitu berisi tentang nasehat kepada masyarakat untuk saling berperilaku dan berbicara menggunakan tatakrama yang baik serta apa 
yang disampaikan memiliki manfaat bagi orang lain. Selanjutnya, nilai yang kedua yaitu nilai tanggung jawab, yang terdiri dari tanggung jawab masyarakat sebagai seorang nelayan dan petani. Nilai tanggungjawab sebagai seorang nelayan digambarkan melalui lirik lagu daerah madura yang berjudul Tandhu ${ }^{\text {ee }}$ Majheng, sedangkan nilai tanggung jawab sebagai seorang petani dicerminkan melalui lirik lagu yang berjudul Pajjhar Lagghu. Inti dari nilai tanggungjawab yang disampaikan melalui kedua lagu tersebut yaitu menjelaskan mengenai masyakarakat yang

memiliki tanggungjawab terhadap satu sama lain, baik dalam hal membantu, gotongroyong saat bekerja dan kerja sama.

\section{DAFTAR PUSTAKA}

Andalas, E. F. (2015). Mitos-Mitos Kabupaten Malang: Cara Orang Jawa dalam Menjelaskan Dunianya. Puitika, 11(2), 150-162.

Andalas, E. F. (2017). Dampak dan Fungsi Sosial Mitos Mbah Bajing bagi Kehidupan Spiritual Masyarakat Dusun Kecopokan Kabupaten Malang Jawa Timur. Puitika, 13(1), 21-31.

Andalas, E. F. (2017). Eskapisme Realitas dalam Dualisme Dunia Alice: Telaah Psikologi-Sastra FIlm Alice in Wonderland (2010). Kembara, 3(2), 185-195.

Andalas, E. F. (2018). Cerita Rakyat dan Tradisi Masyarakat Agraris Nusantara: Mitos Dewi Sri (Jawa) dan Legenda Putri Mandalika (Sasak). In P. Karyanto (Ed.), Kisah-Kisah Perempuan dan Cerita Rakyat Nusantara (pp. 1-12).
Surabaya: Kajian Sastra dan Budaya Universitas Airlangga.

Azhar, I. N., (2009). Karakter masyarakat Madura dalam syair-syair lagu daerah madura. atavisme, 12(02), p. 45. (Online). https://atavisme.web.id/ diakses 20 maret 2018

Bungin, B., (2010). Penelitian Kualitatif: Komunikasi, Ekonomi, Kebijakan Publik, dan Ilmu Sosial Lainnya. Jakarta: Kencana Prenada Media Group.

Faruk, (2014). Pengantar Sosiologi Sastra. Yogyakarta: Pustaka Belajar.

Fatmawati, I., (2017). Cermin budaya masyarakat madura dalam perspektif penyair madura dalam kumpulan puisi "madura: aku dan rindu" karya benazir nafilah. semarang, ELIC Unissula, p. 428.(Online).https://jurnal.unissula.ac.i d/ diakses 21 maret 2018

Marsuki, R. D., (2015). Sikap masyarakat madura terhadap tradisi carok: Studi Fenomenologi Nilai-Nilai Budaya Masyarakat Madura. el harakah, 17(1), p. 74. (Online). https://ejournal.uinmalang.ac.id/ diakses 22 maret 2018

Pradopo, R. D., (2012). Pengkajian Puisi. Yogyakarta: UGM PRESS.

Putri, N. A., (2017). Metafora pengungkap kecantikan dalam masyarakat madura. etnolingual, 1(2), pp. 73-99. (Online). https://e-journal.unair.ac.id/ diakses 11 maret 2018

Rahmat Hidayat, B. W. A. S., (2013). Pangalem bahasa madura di bondowoso (sebuah kajian sosiopragmatik). Publikais Budaya, 1(1), p. 3. (Online). 
https://repository.unej.ac.id/ diakses 11 maret 2018

Rochana, T., (2012). Orang madura: suatu tinjauan antropologis. Humanus, 11(1), p. 49. (Online). https://ejournal.unp. ac.id/ diakses 22 Maret 2018

Saini, J. S. \&., (1988). Apresiasi Kesusastraan. Jakarta: Gramedia.

Salam, B., (1997). Etika Sosial. Jakarta: PT Rineka Cipta.

Sugiarti, \& Andalas, E. F. (2018). Perspektif Etik dalam Penelitian Sastra. Malang: UMM Press.

Sugiyono. (2017). Metode Penelitian Kuantitatif, Kualitatif, dan $R \& D$. Bandung: Alfabeta

Sulistyorini, D., \& Andalas, E. F. (2017). Sastra Lisan: Kajian Teori dan Penerapannya dalam Penelitian. Malang: Madani.

Suseno, F. M. (2004). 13 Model Pendekatan Etika. Yogyakarta: Kanisius.

Suseno, F. M., (1991). Etika Sosial. Jakarta: PT Gramedia Pustaka Utama.

Taufiqurrahman, (2017). Identitas Budaya Madura. Karsa, 11(1), p. 6. (Online). https://ejournal.stainpamekasan.ac.id diakses 22 maret 2018

Yasin, M. F., (2017). Ekspresi nilai filosofis "abantal ombak asapo" angin" dalam sastra madura (kajian analisis semantik komponensial ruth kempson) (the expression of philosophical values "abantal ombak asapo "e angin" in madura literature (the study of ruth kempson componentia. Jurnal Bahasa, Sastra dan Indonesia, p. 78. (Online). https://ppjp.unlam.ac.id/ diakses 11 maret 2018

Zubair, A. C., (1990). kuliah etika. Jakarta : CV

Rajawali. 